2. To: (Receiving Organization)

Distribution

5. Proj./Prog./Dept./Div.:

Spent Nuclear Fuel

8. Originator Remarks:

For approval and release.

11. Receiver Remarks:

11A. Design Baseline Document? [ ] Yes [x] No
3. From: (Originating Organization)

Nuclear Safety

6. Design Authority/ Design Agent/Cog. Engr:

R. Imker
4. Related EDT No.:

N/A

7. Purchase Order No.:

N/A

9. Equip./Component No.:

N/A

10. System/Bldg./Facility:

W-441

12. Major Assm. Dwg. No.:

N/A

13. Permit/Permit Application No.:

N/A

14. Required Response Date:

N/A

\begin{tabular}{|c|c|c|c|c|c|c|c|c|}
\hline IS. & & DAT & NSM & & (F) & (G) & $(\mathrm{H})$ & (I) \\
\hline $\begin{array}{l}\text { (A) } \\
\text { Itent } \\
\text { No. }\end{array}$ & (B) Document/Drawing No. & $\begin{array}{l}\text { (C) } \\
\text { Sheet } \\
\text { No. }\end{array}$ & $\begin{array}{l}\text { (D) } \\
\text { Rev. } \\
\text { No. }\end{array}$ & (E) Title or Description of Data Transmitted & $\begin{array}{l}\text { Approval } \\
\text { Designator }\end{array}$ & $\begin{array}{c}\text { Reason } \\
\text { for Trans- } \\
\text { mittal }\end{array}$ & $\begin{array}{l}\text { Origi- } \\
\text { nattor } \\
\text { Dispo- } \\
\text { sition }\end{array}$ & $\begin{array}{c}\text { Recciver } \\
\text { Disposition }\end{array}$ \\
\hline 1 & SNF-4213 & N/A & 0 & $\begin{array}{l}\text { Human Factors Engineering } \\
\text { Report for the Cold Vacuum } \\
\text { Drying Facility }\end{array}$ & $\mathrm{S}^{\mathrm{N}}$ & 1,2 & 1 & 1 \\
\hline & & & & & & & & \\
\hline & & & & & & & & \\
\hline & & & & & & & & \\
\hline & & & & & & & & \\
\hline & & & & & & & & \\
\hline
\end{tabular}

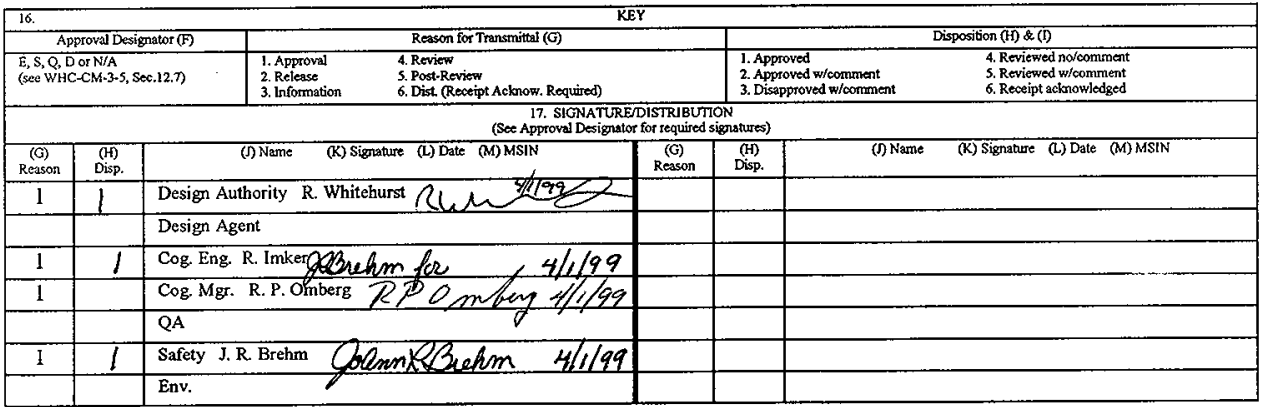
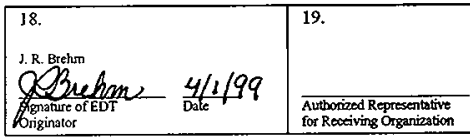

for Reciving Orgnization

Date

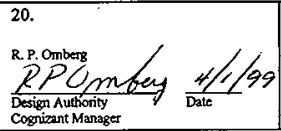

21. DOE APPROVAL (if required)

Ctrl. No.

[] Approved

[] Approved w/comments

[] Disapproved w/comments 


\section{Human Factors Engineering Report for the Cold Vacuum Drying Facility}

R. Imker

DE\&S Hanford, Richland, WA 99352

U.S. Department of Energy Contract DE-AC06-96RL13200

EDT: 626875

Org Code: 2 F200

B\&R Code: EW31354040
UC: 920

Charge Code: $105568 / \mathrm{CB} 80$

Total Pages: 45

Key Words: Cold Vacuum Drying Facility, CVDF, Human Factors, Human Factors Engineering

Abstract: This report describes the design features and steps taken to ensure that the Cold Vacuum Drying Facility satisfies regulatory requirements for human factors engineering.

TRADEMARK DISCLAIMER. Reference herein to any specific commercial product, process, or service by trade name, trademark, manufacturer, or otherwise, does not necessarily constitute or imply its endorsement, recommendation, or favoring by the United States Government or any agency thereof or its contractors or subcontractors.

Printed in the United States of America. To obtain copies of this document, contact: Document Control Services, P.O. Box 950 , Mailstop H6-08, Richland WA 99352, Phone (509) 372-2420; Fax (509) 376-4989.
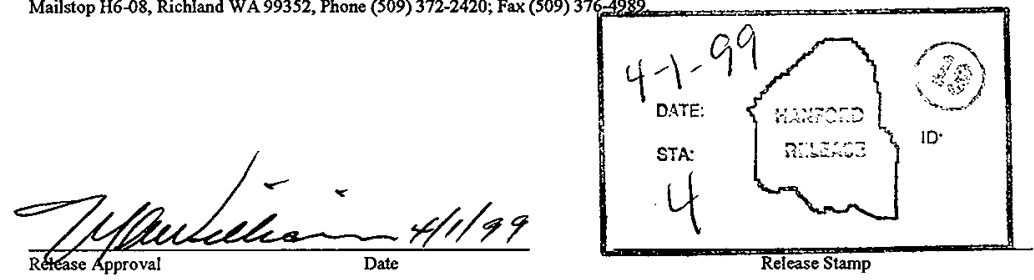

\section{Approved for Public Release}




\section{Human Factors Engineering Report for the Cold Vacuum Drying Facility}

Analysis, Results and Findings

SNF-4213

Revision 0

Prepared by:

Rick Imker, M.A., CPE, MErgS

March 1999 
SNF-4213 REV 0

This page intentionally left blank. 


\section{CONTENTS}

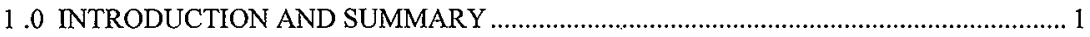

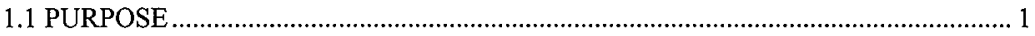

1.2 REQUIREMENT FOR HUMAN FACTORS ENGINEERING ANALYSIS

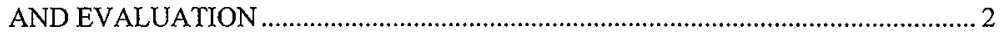

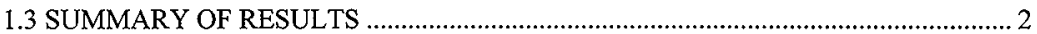

1.4 OVERVIEW OF COLD VACUUM DRYING FACILITY MISSION …....................... 4

1.5 HUMAN OPERATIONS AT THE COLD VACUUM DRYING FACILITY ............... 5

1.6 HUMAN FACTORS ENGINEERING FINAL SAFETY ANALYSIS REPORT

ANALYSIS AND EVALUATION TECHNICAL APPROACH …............................... 6

1.6.1 Identification of Human-Machine Interfaces........................................................ 7

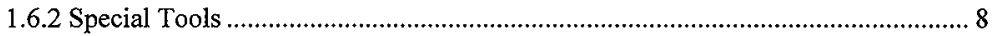

1.6.3 Summary of Compliances and Compliance Deviations ............................................ 8

1.7 DEVIATIONS FROM FULL COMPLIANCE EQUIVALENCE ................................ 12

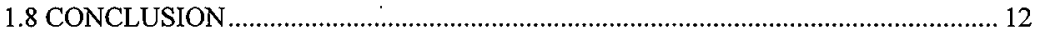

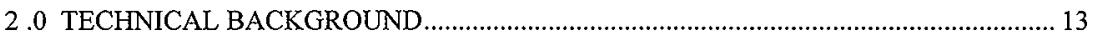

3.0 METHODOLOGY OF FINAL SAFETY ANALYSIS REPORT HUMAN

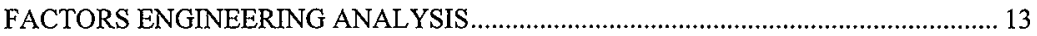

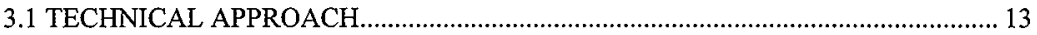

3.2 DESCRIPTION OF HUMAN FACTORS ENGINEERING ANALYSIS TASKS ....... 14

3.3 U.S. DEPARTMENT OF ENERGY REQUIREMENTS AND HUMAN

FACTORS ENGINEERING STANDARDS....................................................... 15

3.4 HUMAN FACTORS ENGINEERING STANDARDS ............................................... 15

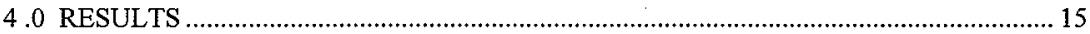

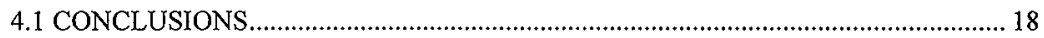

5.0 HUMAN ERROR PERFORMANCE IN POTENTIAL ABNORMAL

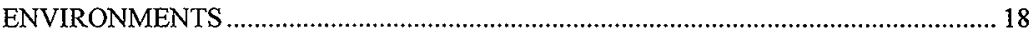

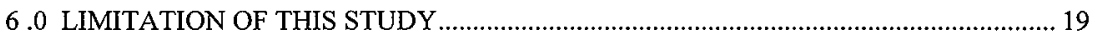

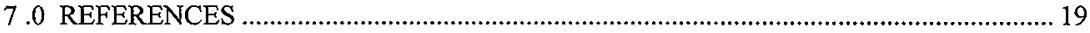

APPENDIX A PICTURES AND ENGINEERING DRAWINGS ........................................... A-1 
SNF-4213 REV 0

\section{LIST OF FIGURES}

Figure 1. Cold Vacuum Drying Facility Process Overview.

\section{LIST OF TABLES}

Table 1. Systems Reviewed for Human Factors Consideration................................................ 9

Table 2. Special Tool Needed to Operate Cold Vacuum Drying Facility. .................................. 11 


\section{LIST OF TERMS}

The following terms appear in numerous places throughout the Spent Nuclear Fuel Project. Some items are peculiar to Cold Vacuum Drying Facility specific systems and subsystems. Other items are peculiar to the Human Factors Engineering bodies of work for this project.

$\begin{array}{ll}\text { ALARA } & \text { as low as reasonably achievable } \\ \text { CVDF } & \text { Cold Vacuum Drying Facility } \\ \text { DOE } & \text { U.S. Department of Energy } \\ \text { FSAR } & \text { final safety analysis report } \\ \text { HEPA } & \text { high-efficiency particulate air } \\ \text { HFE } & \text { Human Factors Engineering } \\ \text { HCI } & \text { human-computer interface } \\ \text { HMI } & \text { human-machine interactions } \\ \text { MCO } & \text { multi-canister overpack } \\ \text { MCS } & \text { monitoring and control system } \\ \text { PWC } & \text { process water conditioning } \\ \text { SAR } & \text { safety analysis report } \\ \text { SCIC } & \text { safety class instrumentation and control } \\ \text { SNF } & \text { spent nuclear fuel } \\ \text { TBD } & \text { to be determined } \\ \text { VDT } & \text { video display terminal (workstation) }\end{array}$


SNF-4213 REV 0

This page intentionally left blank.

snf-4213.doc 
SNF-4213 REV 0

\subsection{INTRODUCTION AND SUMMARY}

\subsection{PURPOSE}

The purpose of this report is to present the results and findings of the final Human Factors Engineering (HFE) technical analysis and evaluation of the Cold Vacuum Drying Facility (CVDF). Ergonomics issues are also addressed in this report, as appropriate. This report follows up and completes the preliminary work accomplished and reported by the Preliminary HFE Analysis report (SNF-2825, Spent Nuclear Fuel Project Cold Vacuum Drying Facility Human Factors Engineering Analysis: Results and Findings). This analysis avoids redundancy of effort except for ensuring that previously recommended HFE design changes have not affected other parts of the system. Changes in one part of the system may affect other parts of the system where those changes were not applied.

The final HFE analysis and evaluation of the CVDF human-machine interactions (HMI) was expanded to include: the physical work environment, human-computer interface ( $\mathrm{HCl}$ ) including workstation and software, operator tasks, tools, maintainability, communications, staffing, training, and the overall ability of humans to accomplish their responsibilities, as appropriate. Key focal areas for this report are the process bay operations, process water conditioning (PWC) skid, tank room, and Central Control Room operations. These key areas contain the system safety-class components and are the foundation for the human factors design basis of the CVDF.

This report makes no attempt to interpret or evaluate the safety significance of the HFE analysis findings. The HFE findings presented in this report combine with the results of the CVDF Safety Analysis Report (SAR) (HNF-SD-SNF-SAR-002, Safety Analysis Report for the Cold Vacuum Drying Facility, Phase 2, Supporting Installation of Processing Systems), Chapter 3, "Hazards and Accident Analysis," to provide the technical basis for preparing HNF-3553, Spent Nuclear Fuel Project Final Safety Analysis Report, Annex B, "CVDF Final Safety Analysis Report," Chapter B13, "Human Factors." Hereafter in this report, HNF-SD-SNF-SAR-002 will be referred to as the Phase 2 CVDF SAR and Annex B of HNF-3553 will be referred to as the CVDF Final Safety Analysis Report (CVDR FSAR).

To maintain continuity, this report will follow the format set out in the Preliminary HFE Analysis report (SNF-2825). 


\subsection{REQUIREMENT FOR HUMAN FACTORS ENGINEERING ANALYSIS AND EVALUATION}

DOE Order 5480.23, Nuclear Safety Analysis Reports, Attachment 1, Section 14, calls out the requirement for performing this HFE work. This order states:

A systematic inquiry be included into the importance to safety of reliable, correct, and effective human-machine interactions, including the effectiveness of surveillance, maintenance, and normal, abnormal, and emergency operations. In those contexts in which reliable effective human performance by the operating crew is important to safety, and in proportion to the importance-to-safety, safety analyses should document a systematic inquiry into the optimization of the design of the human-machine interface to enhance reliable performance.

Human-machine design considerations should include:

14a communication and operational aids

14b layout of controls and instrumentation and labeling

$14 \mathrm{c}$ work environment factors such as heat, light, noise, physical access, protective clothing, and breathing apparatus; and

$14 \mathrm{~d}$ demonstrated ability of personnel to accomplish their responsibilities under normal, abnormal, and accident conditions.

The results and findings presented in this report allow the CVDF FSAR (HNF-3553, Annex B), Chapter B13 to fully respond to the HFE requirements established by DOE Order 5480.23 .

\subsection{SUMMARY OF RESULTS}

This report will show that the CVDF is well designed from the HFE perspective. The CVDF process and equipment designers have given much consideration to HFE. Issues brought to the attention of the designers were handled in a professional manner and, after design trade-off evaluation and cost-benefit analysis, were incorporated as deemed appropriate.

Applicable HFE requirements and criteria found in the U.S. Department of Energy (DOE) orders and standards have been applied to the CVDF design. Four outstanding concerns have been identified that should be investigated for possible improvement:

1. Manual cask-multi-canister overpack (MCO) bolt removal and replacement

2. Manual water hookup at the bottom of the cask and associated newly designed tools 
3. The bridge structure to cross from the mezzanine to the cask-MCO work platform

4. The MCO process connectors connection to MCOs.

Two focus areas identified in the Preliminary HFE Analysis report (SNF-2825) were the monitoring and control system (MCS) and safety-class instrumentation and control (SCIC). These areas were examined in detail and found to meet or exceed HFE checklist criteria. The MCS comprises a total of three control room computers, two operator workstations, and one engineering workstation. A fourth computer station is provided as a supervisor station in the manager's office. The main programmable logic controller control panel is also located in the control room and includes a local alarm and silence button. Four remotely controlled input/output modules with termination panels are located in the bays, one is in the mechanical room, and one is in the PWC tank room.

The MCS HCI is heavily dependent on object-oriented color graphic displays on computer screens. All central processing units are connected on a local area network, which allows simultaneous access to the control system from multiple graphic displays. The system design description for the MCS is contained in SNF-3090, Monitoring and Control System. SNF-2408, System Design Description for the Cold Vacuum Drying Facility Monitoring and Control System, provides for the CVDF MCS software engineering. Also, HNF-2058, Specification for Cold Vacuum Drying (CVD) Project Monitoring and Control System Computer Software Requirements Specification, supports the software design description (SNF-2408) by providing specific requirements in the software engineering (e.g., the exact meaning of colors used in the graphical displays). IEEE Standards Collection, Software Engineering (IEEE 1997) is also consulted by the software engineer(s) to provide additional guidance, as applicable. These references include elements of HFE that are applied across industrial computer-based systems.

During operations, the human operator interfaces with the SCIC system through the mode switch panel in the control room and the safety-class annunciator. Numbers as well as text describing the mode position were added to the mode switches to provide two indications of the required switch position(s). For example, the procedure will state to select " 4 Drying Mode for Bay 2, HS-6000." The annunciator provides industrial standard format for alarm receipt, acknowledgment, and reset.

Overall, the design of the CVDF will meet HFE requirements. No significant changes are anticipated during the system test, verification, and validation phase. Human factors emphasis on the four items listed above, must continue as the design evolves into the system validation phase.

There is still a need for a Human Factors Program Plan that includes monitoring and evaluating changes to the design as the design evolves. It is anticipated that this will be the next HFE project. 


\subsection{OVERVIEW OF COLD VACUUM DRYING FACILITY MISSION}

The CVDF classification is hazard category 2 nonreactor nuclear facility. The purpose of the CVDF essentially is outlined in three parts: (1) to accept casks with inserted MCOs containing spent nuclear fuels; (2) to remove free water from the spent nuclear fuels using a technical process; and (3) to prepare the cask-MCOs for transport to the Canister Storage Building. The CVDF provides the required technical process systems, supporting equipment, and facilities needed to support this purpose. The cold vacuum drying process involves draining of bulk water from the MCOs and subsequent vacuum drying. After vacuum drying, the MCOs are back-filled with helium. Removal of free water from the MCOs is necessary to reduce the potential for fuel-water corrosion.reactions that could lead to $\mathrm{MCO}$ overpressurization at the Canister Storage Building. Figure 1 shows an overview of the CVDF process.

Figure 1. Cold Vacuum Drying Facility Process Overview.

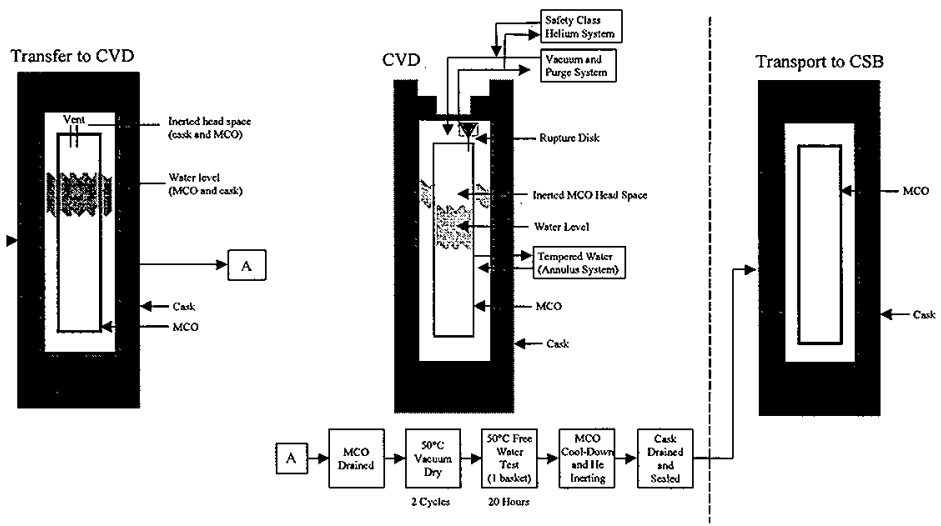

The CVDF contains equipment to prepare solid waste generated by the cold vacuum drying process for interim storage prior to disposal. The CVDF also prepares contaminated process water from the MCOs for transport back to the K West Basin facility. The CVDF building design includes five process bays that each can accommodate MCOs shipped on specially designed transporters from the K Basins. However, the normal CVDF operational configuration uses only four processing bays (bays 2 through 5 ).

Human system interaction within the CVDF focuses mainly on two important areas: the process bay(s) and the Central Control Room. The process bay provides direct human access to the cask-MCO and exposes the human operator to a moderate risk. The control room provides the human operator a means for surveillance, management, and control over the cask-MCO 
processing operation(s). For purposes of the human factors safety basis, the control room is a non-reactor control room. The Phase 2 CVDF SAR (HNF-SD-SNF-SAR-002), Chapter 2, "Facility Description," presents a complete facility description.

\subsection{HUMAN OPERATIONS AT THE COLD VACUUM DRYING FACILITY}

The normal human operations at the CVDF are detailed in SNF-2356, Spent Nuclear Fuel Cold Vacuum Drying Facility Operations Manual. These operations are outlined below.

- Operators connect hoses to the tractor exhaust and hook up building air.

- Operators raise the bay door to allow the transporter to back into the predetermined position. Location marks are painted on the floor to facilitate the transporter parking position. The tractor drives out of the bay and the bay door closes, achieving process bay confinement. The transporter is stabilized and leveled. The security system for the specific bay activates. The radiological control technician conducts radiation surveys on the cask and transporter. The CVDF shift operations supervisor receives the shipping data package. The operators install a bridge from the process bay mezzanine to the transporter work platform. The operators prepare the cask lid for removal.

- Special venting hardware and flex lines connect to the cask lid port and the CVDF process vent system. After cask venting is completed, the CVDF process bay overhead crane removes the cask lid, the process hood-seal ring is installed on the cask, process connectors are manually attached to $\mathrm{MCO}$ process port covers, and the $\mathrm{MCO}$ is prepared for process operations.

- There are minimal manual operator actions in the process sequences other than field operator actions (e.g., connecting the MCO valves and flex lines) or control room operator actions (e.g., acknowledging alarms or instructing the MCS to proceed with the next step in the operation). Control room operators direct the MCS to initiate a certain sequence based on status updates from field operators and the MCS, previous sequence completion notification, and operating procedures. This includes draining the cask-MCO annulus.

- Following the cold vacuum drying process and $\mathrm{MCO}$ testing, the cask-MCO transporter is prepared for shipment to the Canister Storage Building. This operation is basically the reverse of the receipt operation. Through operations controlled via the MCS, the cask-MCO is cooled and the MCO is inerted and pressurized with helium, sealed, and leak tested. The cask annulus is drained and dried with an instrument air purge, and the cask lid is reinstalled. The bay is isolated from the ventilation systems, and the telescoping door is opened. The transporter is reconnected to the tractor and released for shipment to the Canister Storage Building. 
The CVDF is designed to drain and dry spent nuclear fuel elements contained within a sealed vessel (cask-MCO). The normal operating sequences and subsystems associated with this facility are:

\section{OPERATING SEQUENCE}

Initial start-up/water heatup to $50^{\circ} \mathrm{C}$ Draining operation

Drying operation

Tempered water refill

Cool down operation

Initial start-up action and then stays on-line

Shipping preparation

\section{SUBSYSTEMS}

Gas supply system (HE)

Tempered water system (TW)

Vacuum pumping system (VPS)

De-ionized water system (DI)

Process water conditioning (PWC)

Control air $(\mathrm{CA})$ ventilation

None

There are periodic nonintrusive routine maintenance requirements (the CVDF does not need shutting down) that require recalibration of instruments and possible high-efficiency particulate air (HEPA) filter changes. The probability of major failure with the resulting removing and replacing of major items, such as pumps, is extremely low. The systems are expected to last the entire life cycle of the facility, which is stated as five years.

Almost all human operator functional activities will be in the process bay, the PWC tank room (ion-exchange module changeout), and the Central Control Room.

\subsection{HUMAN FACTORS ENGINEERING FINAL SAFETY ANALYSIS REPORT ANALYSIS AND EVALUATION TECHNICAL APPROACH}

The final HFE analysis and evaluation did consider HFE requirements established by DOE Order 5480.23, Attachment 1, Section 14, and commensurate with the following design basis:

- Planned CVDF mission as described in HNF-3553, Chapter 2, "Facility Description"

- The hazard category 2 classification

- Complexity of the CVDF, including operator actions

- Safety-related structures, systems, and components

- CVDF process operation as currently designed and described by Engineering. 
The methodology for evaluating whether the final design and the specifications and processes meet or exceed HFE criteria, standards, principles, and guidelines is summarized as follows:

- Review the current state of the project with the previous HFE analyst, design authorities, and cognizant project engineers

- Observe and participate in operator activities using the CVDF full-scale mock-up facility

- Reapply the applicable checklists to the final design

- Review available relevant engineering specifications and reports, technical drawings and blueprints, and Requests for Procurement

- Study applicable chapters in the Phase 2 CVDF SAR (HNF-SD-SNF-SAR-003)

- Visit the CVDF physical environment

- Direct an interview with the training development specialist

- Study the CVDF operations manual (SNF-2356)

- Conduct a direct interview with the software designer

- Review all formal comments to the CVDF SAR (HNF-SD-SNF-SAR-003), Chapter B13

- Participate in applicable meetings with Engineering or SAR development personnel.

(Note: Further details are provided in Section 3.2 of this report.)

The methodology describes a rigorous process for completely examining the HFE issues and compliance. This HFE analysis is primarily a paper-based design activity, with assessments of either the available prototyping equipment, vendor-supplied equipment, or in-place facilities waiting for pre-operational checkout. This analysis uses the same NNEL-95/0117, Human Factors Engineering Checklists for Application in the SAR Process, as was used for the Preliminary HFE analysis. This creates continuity in the effort by evaluating the items that were not covered in the preliminary phase.

\subsubsection{Identification of Human-Machine Interactions}

This section summarizes the safety-class and safety-significant subsystems that require HMI to function and the associated HMI. Also annotated are the significant HMIs that are pertinent to the operation of the CVDF. The intent during design to reduce CVDF HMI, as much 
as possible, is notable. The system is designed to run efficiently in an automated state; however, human input (e.g., providing permission for the system to move from one process to the next process) ensures that the system is maintained under human control through all processes and keeps the human operator involved at critical stages of the process operation. The human also will monitor the system operation. When there is an off-normal occurrence, the human accomplishes a physical check of the discrepant part of the system. Periodic human inspection of the system and routine periodic maintenance will also be required.

Using the DOE-recommended graded approach, the analyst performs a systems requirements analysis as an integral part of the design. HNF-SD-SNF-DRD-002, Cold Vacuum Drying Facility Design Requirements, includes a number of human factors considerations in the CVDF design. In addition, U.S. Nuclear Regulatory Commission equivalency requires that NUREG 0700, Human System Interface Design Review Guideline, and NUREG 0800, Standard Review Plan, be reviewed for additional applicable requirements over and above DOE guidelines. Application of these guidelines to the CVDF for human factors interfaces is documented for the safety-related structures, systems, and components. Table 1 shows the systems that were reviewed for human factors considerations; additional details concerning HFE analyses of these systems and operator task analysis are developed in Section 4.0 of this report.

\subsubsection{Special Tools}

Several special tools are required to operate the CVDF. Table 2 is a list of known special tools required to operate the process. The list is not intended to be all-inclusive, nor does it identify all necessary components for maintenance of the process skids or facility (skid special tools will be identified by the vendor at a later time).

\subsubsection{Summary of Compliances and Compliance Deviations}

This analysis did not duplicate the previous work, but rather examined the analysis needs to determine how to complete the final analysis. As stated in the Preliminary HFE Analysis report (SNF-2825), approximately 10,000 HFE criteria are contained in DOE and DOEreferenced HFE standards and are identified as appropriate for analyzing the CVDF. The 19 checklists corresponding to the DOE requirements for communications, operational aids, instrumentation and control, and environmental factors, were used.

This analysis focused on the 21 "non compliance" issues identified in the Preliminary HFE Analysis report (SNF-2825). These issues were investigated for resolution. The 797 "tobe-determined" (TBD) issues were examined also. The MCS contained the majority of the TBD issues. In addition, some of the interview questions considered in the preliminary HFE analysis were not completely answered and are studied in more detail in this report. 
Table 1. Systems Reviewed for Human Factors Consideration

\begin{tabular}{|c|c|c|}
\hline System reviewed & Significant HMI & HFE criteria compliance \\
\hline $\begin{array}{l}\text { Safety class } \\
\text { instrumentation and } \\
\text { control system }\end{array}$ & $\begin{array}{l}\text { Control panel located in the Control Room } \\
\text { provides an audible alarm to differentiate } \\
\text { this system from the monitoring and } \\
\text { control system. Responses will be } \\
\text { automatic. HMI is through test switches } \\
\text { and reset functions. }\end{array}$ & $\begin{array}{l}\text { Yes, meets applicable HFE general design } \\
\text { criteria. }\end{array}$ \\
\hline $\begin{array}{l}\text { Safety class helium } \\
\text { system }\end{array}$ & $\begin{array}{l}\text { Check gauges and test/replace helium } \\
\text { cylinders as required. }\end{array}$ & $\begin{array}{l}\text { Yes, meets applicable HFE general design } \\
\text { criteria. }\end{array}$ \\
\hline $\begin{array}{l}\text { Safety class annulus } \\
\text { water protection system }\end{array}$ & $\begin{array}{l}\text { Connect to tempered water system } \\
\text { disconnect, flush. }\end{array}$ & $\begin{array}{l}\text { Yes, fed into control room and safety-class } \\
\text { annunciator alarm (long-handled tools are } \\
\text { being redesigned and will need HFE follow- } \\
\text { up). }\end{array}$ \\
\hline Cask-MCO & $\begin{array}{l}\text { Inspect and decontaminate cask lid. } \\
\text { Check rupture disc. } \\
\text { Unbolt twelve } 300 \text {-ft-lb torque bolts, } \\
\text { remove cask lid with overhead crane, } \\
\text { install protection ventilation hood, remove } \\
\text { cask cover plate for tempered water, hook } \\
\text { up tempered water hoses. Remove } \\
\text { hood/seal ring. Install cask lid and torque } \\
12 \text { bolts by hand tool to } 300 \text { ft-lb } \pm 10 \% \text {. }\end{array}$ & $\begin{array}{l}\text { Not complete because of HFE } \\
\text { recommended design changes given to } \\
\text { design authorities. Requires further HFE } \\
\text { monitoring (as part of the Human } \\
\text { Engineering Program Plan) to ensure that } \\
\text { ergonomics (biomechanical) considerations } \\
\text { related to special tools and torque wrenches } \\
\text { are included. }\end{array}$ \\
\hline MCO (process port) & $\begin{array}{l}\text { Remove and insfall process connectors; } \\
\text { same with covers. }\end{array}$ & $\begin{array}{l}\text { Yes, process port connectors and valve } \\
\text { operators are spring-tensioned to start, then } \\
\text { manually torqued and valve torqued. Need } \\
\text { to monitor installation of bolts with gloved } \\
\text { hand. }\end{array}$ \\
\hline $\begin{array}{l}\text { Process equipment and } \\
\text { PWC skids }\end{array}$ & $\begin{array}{l}\text { Routine maintenance, as required. Valve } \\
\text { lineups and drain condensate. Major } \\
\text { maintenance if valve fails. Electrical } \\
\text { (instrument calibration) interfaces and } \\
\text { mechanical interfaces within code } \\
\text { compliance. }\end{array}$ & $\begin{array}{l}\text { Yes, however, need to re-verify accessibility } \\
\text { areas (reading gauges, levers, filter } \\
\text { changeout) with the selected vendor during } \\
\text { acceptance tests. }\end{array}$ \\
\hline Overhead crane & $\begin{array}{l}\text { HMI with control (six control buttons), } \\
\text { grappling hook has to be maneuvered } \\
\text { from lid to hood to lid. }\end{array}$ & $\begin{array}{l}\text { Yes, meets Hanford crane and ANSI crane } \\
\text { specifications. Will have six control buttons } \\
\text { in a standard configuration used on Hanford } \\
\text { Site. }\end{array}$ \\
\hline $\begin{array}{l}\text { Heating, ventilation, } \\
\text { humidity control, air- } \\
\text { conditioning, lighting, } \\
\text { vibration, noise } \\
\text { (Environmental System) }\end{array}$ & $\begin{array}{l}\text { Environment is designed using accepted } \\
\text { national codes and standards. There is } \\
\text { no actual HMI, except for routine } \\
\text { maintenance and possible HEPA filter } \\
\text { changes }\end{array}$ & $\begin{array}{l}\text { Yes, meets HFE applicable general design } \\
\text { criteria and guidelines. } \\
\text { Maintenance accessibility and labeling are } \\
\text { well planned. }\end{array}$ \\
\hline
\end{tabular}


Table 1. Systems Reviewed for Human Factors Consideration

\begin{tabular}{|c|c|c|}
\hline System reviewed & Significant HMI & HFE criteria compliance \\
\hline CVDF structures & $\begin{array}{l}\text { No HMI during operations, except } \\
\text { manually maneuvering bridge between } \\
\text { mezzanine and cask-MCO work platform. } \\
\text { There are } 25 \text { steps from the floor of the } \\
\text { process bays to the mezzanine area. }\end{array}$ & $\begin{array}{l}\text { Meets HFE general design criteria and } \\
\text { guidelines. All equipment requiring routine } \\
\text { maintenance will have met accessibility } \\
\text { requirements. Labeling meets applicable } \\
\text { HFE guidelines. Bridging technical design, } \\
\text { not known at this time, how operator will } \\
\text { accomplish this task. }\end{array}$ \\
\hline $\begin{array}{l}\text { Monitoring and control } \\
\text { system }\end{array}$ & $\begin{array}{l}\text { Significant } \mathrm{HCl} \text { using computers, } \\
\text { monitors, and mouse-input devices. } \\
\text { Complex screen presentations (object- } \\
\text { oriented color displays). Response to } \\
\text { both auditory and visual alarms, as } \\
\text { appropriate. Continuous monitoring } \\
\text { activity. }\end{array}$ & $\begin{array}{l}\text { Software design considers } \mathrm{HCl} \text {, including } \\
\text { NUREG-0700 guidelines. Software also } \\
\text { considers IEEE standards for guidance and } \\
\text { insight. Will meet applicable general HFE } \\
\text { design guidelines. Meets applicable HFE } \\
\text { checklist for software design considerations. } \\
\text { Need to consider administrative procedures } \\
\text { to reduce continuous monitoring by human. }\end{array}$ \\
\hline Communication system & $\begin{array}{l}\text { None, except for use during normal and } \\
\text { abnormal operations }\end{array}$ & Yes, complies with applicable HFE criteria. \\
\hline $\begin{array}{l}\text { Process water recovery } \\
\text { and skid (ion-exchange } \\
\text { module changeout) }\end{array}$ & $\begin{array}{l}\text { Limited HMI, routine maintenance. } \\
\text { Periodic draining of tank. }\end{array}$ & $\begin{array}{l}\text { Yes, but check test and validation phase for } \\
\text { skid accessibility requirements. }\end{array}$ \\
\hline Central Control Room & $\begin{array}{l}\text { Two operators using computers to } \\
\text { monitor and control CVDF processes. } \\
\text { Video display terminal workstations. }\end{array}$ & $\begin{array}{l}\text { Yes, workstations are well designed with } \\
\text { maximum adjustability. Above-average } \\
\text { ergonomically designed chairs provided. } \\
\text { Potential glare on the computer screen } \\
\text { concerns with lighting. }\end{array}$ \\
\hline $\begin{array}{l}\text { Tempered water } \\
\text { system(same as safety } \\
\text { class annulus water) }\end{array}$ & $\begin{array}{l}\text { No HMI necessary, except for routine } \\
\text { maintenance (e.g, refill retention tank with } \\
\text { water). }\end{array}$ & Not applicable. \\
\hline
\end{tabular}

ANSI = American National Standards Institute.

CVDF $=$ Cold Vacuum Drying Facility.

HEPA = high-efficiency particulate air (filter).

$\mathrm{HFE}=$ human factors engineering.

$H \mathrm{MI}=$ human-machine interactions.

IEEE = Institute of Electrical and Electronics Engineers, Inc.

$\mathrm{PWC}=$ process water conditioning . 
Table 2. Special Tool Needed to Operate Cold Vacuum Drying Facility.

\begin{tabular}{|c|c|}
\hline Special tool & Description \\
\hline $\begin{array}{l}\text { Cask lid bolting torque wrench and } \\
\text { sockets }\end{array}$ & $\begin{array}{l}\text { A torque wrench with extension and sockets for the cask lid } \\
\text { bolts is provided for each bay. Various sizes of wrenches and } \\
\text { pneumatic tools will be available for use in each bay. }\end{array}$ \\
\hline $\begin{array}{l}\text { Cask lid bolting torque wrench calibration } \\
\text { standard }\end{array}$ & $\begin{array}{l}\text { A torque wrench calibration standard is to be provided at the } \\
\text { CVDF for periodic calibration of the cask bolting torque } \\
\text { wrenches. }\end{array}$ \\
\hline Cask drain port tools & $\begin{array}{l}\text { Tools are provided for each bay to remove and install the } \\
\text { cask drain port cover and to install the tempered water lower } \\
\text { cask port connection. (NOTE: these tools are undergoing } \\
\text { redesign to meet newly imposed requirements for safety } \\
\text { class.) }\end{array}$ \\
\hline Cask vent port tool & $\begin{array}{l}\text { A tool is supplied for each bay to remove and replace the } \\
\text { cask vent port. }\end{array}$ \\
\hline $\begin{array}{l}\text { MCO process port cover removal and } \\
\text { installation tool }\end{array}$ & $\begin{array}{l}\text { A tool is supplied for each bay to remove and install the MCO } \\
\text { process port covers (torque wrench and sockets). }\end{array}$ \\
\hline $\begin{array}{l}\text { MCO process port connector installation } \\
\text { tool }\end{array}$ & $\begin{array}{l}\text { A tool (torque wrench and sockets) is supplied for each bay to } \\
\text { remove and install the MCO process port connector and to } \\
\text { open and close the MCO port plugs. }\end{array}$ \\
\hline $\begin{array}{l}\text { PWC and vacuum pumping system } \\
\text { process skid tools }\end{array}$ & $\begin{array}{l}\text { Tools, other than standard, required for the maintenance of } \\
\text { the PWC system and VPS and TWS are supplied with the } \\
\text { equipment. }\end{array}$ \\
\hline HEPA filter changeout tools & $\begin{array}{l}\text { Tools, other than standard, required for the removal of the } \\
\text { HEPA filters from the filter housings are supplied with the } \\
\text { equipment. }\end{array}$ \\
\hline $\begin{array}{l}\text { Instrumentation and controls calibration } \\
\text { tools }\end{array}$ & $\begin{array}{l}\text { Calibration tools are supplied to verify and recalibrate } \\
\text { instrumentation. }\end{array}$ \\
\hline
\end{tabular}

CVDF = Cold Vacuum Drying Facility.

HEPA = high-efficiency particulate air (filter).

$\mathrm{MCO}=$ multi-canister overpack.

PWC = process water conditioning.

TWS = tempered water system.

VPS = vacuum and purge system. 


\subsection{DEVIATIONS FROM FULL COMPLIANCE EQUIVALENCE}

The Preliminary HFE Analysis report (SNF-2825) states:

The results of the HFE analysis also demonstrate that all types of deviations from full compliance are not equal in their implications for CVDF, nor do deviations from full compliance of a single type necessarily have identical implications. Different HFE compliance criteria have different overall impacts on safety, and the same criteria can have different impacts on safety for different pieces of equipment and building areas.

The interpretation and application of HFE criteria is considered by the HFE analyst during the HFE design support process. In many instances good judgment based on experience is called upon when analyzing systems and their components. The HFE analyst will identify concerns and make recommendations and suggestions to the cognizant design engineers. The final design is a combination of many trades-offs, with safety always paramount. This report does not consider human reliability per se, but the information provides additional data used to support human reliability analysis considered in the Phase 2 CVDF SAR (HNF-SD-SNF-SAR-002), Chapter 3, "Accident Analysis."

\subsection{CONCLUSION}

HFE design support for the CVDF has received excellent attention from the cognizant design engineers. The level of compliance with HFE criteria applicable to the design is well within acceptable limits. These limits are based on the criteria, the experience and judgment of the analyst, and the trade-offs made in the design to accommodate the human component. The availability of the engineers, the design aids (e.g., full-scale mock-up and MCS software progress), and the actual CVDF building all contributed to better understanding how the human component is integrated into the system.

There are two concerns regarding ergonomics, in the area of "biomechanics." These concerns have to do with the tasks involving the cask-MCO lid bolts removal and installation, and the task of removing and installing the cask-MCO plug and water hookups. The lid bolts removal and installation involves manually torquing up to $300 \mathrm{ft}-1 \mathrm{~b}( \pm 10 \%)$ on each of the 12 bolts. A 6:1 ratio torque multiplier is designed into the task, reducing the manually applied torque to $50 \mathrm{ft}-\mathrm{lb}$, at operator approximate mid-chest level. This was a trade-off between the human component and using expensive automated multi-spindle torque tools that also may have impacted the facility design regarding installation. This concern needs to be studied further as the design moves into the test and validation phase.

The cask-MCO plug, connection of process connectors and operation, and water hookup present a problem because of as low as reasonably achievable (ALARA) requirements (at the bottom of cask). Trade-offs were considered in design of the tools, and redesign has resulted in 
shortening of the tools used in the tasks associated with plug removal and installation and with water hookup and disconnect. This concern should be further studied during the test and validation phase.

The Central Control Room and associated tasks appear well thought out and designed for human use. The MCS design is following accepted software design standards for both DOE and industry requirements. In addition, engineers working on software have personal experience in working in a nuclear power plant control room and intimately understand the complexity of HCI. The engineers are able to anticipate the needs of the operator and have taken operator suggestions (during mock-up trials) to reduce the complexity of the MCS to its lowest practical level. The MCS is highly intuitive in design, and there may be a few additional changes before the system is tested and validated.

The process bay bridge from the mezzanine to the cask-MCO work platform should be further studied during the test and validation phase of the project.

CVDF HFE design appears to provide workstations, building, and HMIs directed toward maintaining the safety envelope for operators, co-located workers, and the public.

\subsection{TECHNICAL BACKGROUND}

The technical background used for this report is provided in the Preliminary HFE Analysis report (SNF-2825).

\subsection{METHODOLOGY OF FINAL SAFETY ANALYSIS REPORT HUMAN FACTORS ENGINEERING ANALYSIS}

\subsection{TECHNICAL APPROACH}

The CVDF is classified as a hazard category 2 facility based on criteria established in DOE-STD-1027-92, Hazard Categorization and Accident Analysis Techniques for Compliance with DOE Order 5480.23, Nuclear Safety Analysis Reports, and annotated in the CVDF FSAR (HNF-3553). The technical approach of the HFE analysis was guided by the same CVDF characterizations as annotated in the Preliminary HFE Analysis report (SNF-2825).

The normal operation, as annotated in the CVDF operations manual (SNF-2356), reveal minimal human interaction with the CVDF facility. The most important human interaction with CVDF occurs in the process bays, process water tank room, and the Central Control Room. During normal operations, the human operator is responsible for connecting and disconnecting venting/purging process systems to the cask-MCO and monitoring its progress. Activity in the Central Control Room is devoted mostly to monitoring the MCS and giving periodic human permission for the automated operation to sequence. 
During off-normal activities, if the system has halted processing, the human operator will not allow the process to continue until the cause is determined and corrected. The system will automatically stop for most off-normal situations, some situations will only be noted in the computer logging of the process and are not considered serious enough to halt the sequencing. The system will correct for these minor variation situations automatically.

In summary, the final HFE analysis described in this report considers HFE requirements established by DOE Order 5480.23, Attachment 1, Section 14, and DOE Order 6430.1A, General Design Criteria, Section 1300-12.

\subsection{DESCRIPTION OF HUMAN FACTORS ENGINEERING ANALYSIS TASKS}

The final HFE analysis was performed from November to December 1998 and updated again in March 1999. The same preliminary analysis tasks (see SNF-2825) were accomplished for those items still considered TBD or noncompliant. This involved the tabletop analysis, application of appropriate checklists, and analyses of HMI in the HFE compliance categories listed in the applicable checklist.

In addition, because the design is near its final configuration, there were additional opportunities to supplement the checklists. Some of these were annotated in Section 1.6 of this report; some of the additional opportunities for CVDF analyses were:

- Review the current state of the project with the previous HFE analyst and review the Preliminary HFE Analysis report (SNF-2825), including examining the Spent Nuclear Fuel (SNF) Project HFE requirements and associated design standards

- Conduct direct interviews and periodic reinterviews with the design authorities and cognizant project engineers, as appropriate

- Observe and participate in operator activities at the available CVDF full-scale mock-up facility; conduct direct interviews with the operators-in-training at the mock-up facility

- Review available relevant engineering specifications and reports, technical drawings and blueprints, and Requests for Procurement

- Visit the CVDF, which is in the final stages of construction, and examine how the operators will be working in this physical environment; look for obvious weaknesses in the HMIs

- Direct an interview with the training development specialist to solicit any Human Engineering Deficiencies problems uncovered from the training aspect 
- Study the CVDF operations manual (SNF-2356) in detail to understand the system and the operator requirements, and compare this to the mock-up studies; study the tasking (task analysis) and examine areas where potential human error would occur

- Conduct a direct interview with the software designer and study the MCS and SCIC to better understand the $\mathrm{HCI}$

- Review the all formal comments to the Phase 2 CVSF SAR, Chapter B13

- Attend applicable meetings with Engineering or SAR development personnel.

Remaining HFE analyses will consist of the test and validation phase (pre-operational test) of the project. Step-by-step walkthroughs of the CVDF operation and maintenance activities will be performed to verify the HFE analyses, recommendations, and suggestions. In addition, periodic HFE follow-up of the CVDF in full operation should be accomplished.

\subsection{U.S. DEPARTMENT OF ENERGY REQUIREMENTS AND HUMAN FACTORS ENGINEERING STANDARDS}

These requirements and standards did not change from the preliminary $\mathrm{HFE}$ analysis and may be reviewed in the Preliminary HFE Analysis report (SNF-2825).

\subsection{HUMAN FACTORS ENGINEERING STANDARDS}

The same standards and criteria annotated for the preliminary HFE analysis also apply to the final HFE analyses (see the Preliminary HFE Analysis report [SNF-2825] for description).

\subsection{RESULTS}

In reference to the Preliminary HFE Analysis report (SNF-2825), the CVDF was found to be in compliance with $99 \%$ of the HFE criteria that it measured. Therefore, follow-up of the noncompliance issues is addressed. In addition, the MCS was well enough along in design to permit a meaningful evaluation.

The following information will be used to update the previous tables and results included in the Preliminary HFE Analysis report (SNF-2825).

- Crane. The overhead crane meets all applicable checklist items. Crane design and human interface (control) are in accordance with standard industry specifications, and control design is typical of that used elsewhere on the Hanford Site for similar operations. At this time there are no human-interface concerns with the crane. 
- SCIC. The HMI meets all applicable checklist items. The SCIC panel design was studied for HFE inputs and found to be acceptable. The SCIC alarm system is differentiated from the MCS alarm to indicate to the operator which alarm system is activated. The SCIC is virtually automatic in operation. Main human interfacing is testing the system and operationally placing the mode switch in the proper position during the phases of the process cycles. The SCIC should be checked again, at test phase, when the system is finally installed.

- Process Skid. Evaluation of the mock-up appeared to indicate that there may be some concerns with the gauges and with accessibility. The procurement specification addresses these concerns and indicates that HFE must be considered (e.g., all gauges must be designed to be read by a person standing on the floor). The human factors analyst suggested that HFE considerations be demonstrated by the vendor during acceptance testing to ensure accessibility concerns were eliminated. It is possible for maintenance personnel to access the necessary functions for routine maintenance, but this must be rechecked with acceptance testing. Labeling on the skid is called out in detail in the design/procurement specification and meets or exceeds HFE standards. There may be a concern with the label attachment method (handing on wire loops) in that the wire loops must be designed so as not to cut an operator's bare hand; this is a quality control issue. One other point regarding the skid is the rounding of appropriate corners to avoid injury to the operators or maintenance personnel working in and around the skid. The mock-up revealed that several areas should be re-examined and machined to round off corner areas.

- MCO and Equipment: The process connectors "T-handle" mechanisms were evaluated by the operators at the mock-up facility. It was decided that the $T$-handle mechanisms were superfluous and a hindrance. The design should be changed to remove the $T$-handles. The operator simply maneuvers the process connectors while holding onto the connector piping itself (now known as the "Viking helmet"). The piping serves as a "handle," and there appears to be no engineering problem with using the piping as a "handle." The process hood is maneuvered into place using the overhead crane, the operator manually guides the hood into proper position. It was noted at the mock-up that the hood design should incorporate a rounded edge where the operators may rest their arms while working with the process connectors. The other concerns with the cask are as follows:

- The 12 bolts must be manually un-torqued and re-torqued with $300 \mathrm{ft}-\mathrm{lb}$ $( \pm 10 \%)$ of force. The plan is to use a torque multiplier to assist in this task. The torque multiplier will use a ratio of $6: 1$ to bring the physical human effort down to $50 \mathrm{ft}-\mathrm{lb}$. The torquing sequence for the bolts must be followed exactly according to engineering requirements. Thus, this job will require two persons working with six bolts per person per cask. Weighing considerations such as cost-benefit and duty time with this task, it is the opinion that the job is doable. Consulting MIL-STD-1472E (Department of Defense Design Criteria 
Standard, "Human Engineering,") with high traction (coefficient of $>0.9$ ), it is possible that a manual push/pull force of $70 \mathrm{lb}$ may be applied with both hands. This also considers the push/pull force is exerted intermittently for short periods of time and also is measured for male personnel.

- The other concern involves the method of removing and installing both the lower cask access plate and the water hookups, using two tools. The tools to do this task are being redesigned to shorten the length of the tools. A factor that must be weighed in the design is the ALARA requirements because of possible contamination levels in this area. Therefore, there has to be a tradeoff to accept a cumbersome tool to comply with the required ALARA minimum distance. One way to assist with the tool handling is to possibly include a handle on top of the rod to allow for easier grasping and reduction of biomechanical forces at the operator's wrist. The addition of a second operator to assist with water hookup lines and cover removal and installation may be another approach.

- MCS. The MCS is located in the Central Control Room. The design of screen presentations and alarms meets applicable HFE criteria presented on the checklist review. The HCI appears well designed using the computer software requirements specification (HNF-2058). NUREG-0700 design criteria have been incorporated as applicable. The design provides for two operators in the Central Control Room, each monitoring two bays using video display terminals (VDTs). All systems can be monitored through the computer systems in the control room. The operators will be able to interact with the systems via the VDTs (mouse and separate keyboard based). Operators are alerted to off-normal conditions and take the appropriate actions. The Central Control Room work environment is planned for installation of fully adjustable ergonomically designed seating and fully adjustable computer workstations, both for the keyboard and for the monitor platforms. Operators will be able to adjust the VDT workstations to accommodate their particular needs. Operators using the mock-up facility have interacted well with the design engineers to make changes in the system design, as appropriate, and to allow increased operator efficiency in using the system. Information overload is being considered and reduced, as appropriate.

One of the primary human concerns with the MCS is the efficiency of the MCS. The system will run virtually automatically in the normal mode of operation. The human provides the permission signal for the system to move from one sequence to another. This is a relatively inactive mode of operation for the human, so other administrative considerations may need to be included. Also, shift scheduling will be important to manage. Because of the location of the facility, there is a long drive (privately owned vehicles provide the transportation) for the operator to get home. This introduces the possibility of fatigued operators driving their cars home, after long days at the facility. The current idea is for three 8-hour shifts; this would be appropriate. 
- Environments. The work environments are well designed regarding ventilation, lighting, noise, and temperature. The facility design criteria meet applicable codes and call out specific temperature and humidity criteria with seasonal adjustments. These are well within the comfort zone for the personnel working within the facility. Lighting calculations and examination of the Central Control Room data were completed. These calculations appear to meet illuminance requirements for the VDT work surfaces. Since the lighting calculations were completed, a third ceiling fixture is being added to the Central Control Room. New calculations may need to be completed. One possible concern is the presence of glare on monitor screens. This may be examined during the test and validation phase, and glare filters may be used on the computer monitor screens. Lighting control (brightness) should be an operator function.

- Training. Training is being designed based on DOE requirements for performancebased training. This ensures the personnel will be adequately trained in the performance of their work. Performance-based training provides a means to measure the outcome of the training and is widely used throughout the DOE.

- Staffing. These considerations are discussed more fully in the CVDF FSAR (HNF-3553).

\subsection{CONCLUSIONS}

The CVDF process and equipment designers have considered HFE issues as very important to their design. HFE design support recommendations and suggestions are included in redesign where appropriate after considering the design trade-offs. CVDF will continue to maintain HFE as a requirement during the procurement activities and during test and evaluation. In addition, it is planned that HFE will be periodically reviewed after the CVDF goes into full operation, as a continuing follow-up of the system design.

Additional information concerning HMI philosophies confronting the HFE analyst will not be repeated in this final report, to reduce redundancy. The Preliminary Safety Analysis report (SNF-2825) may be consulted for additional information.

\subsection{HUMAN ERROR PERFORMANCE IN POTENTIAL ABNORMAL ENVIRONMENTS}

Human error, as opposed to human reliability, was discussed in the Preliminary HFE Analysis report (SNF-2825). The main theme is that the SCIC is a system requiring little human intervention. The system is designed to respond to an incident and place the MCO in a safe configuration to ensure little opportunity for contaminated material release. Human error will continue to be evaluated right up to system full operations. The test and validation phase will contribute to detecting further potential human error. Much of the human error may occur by not 
following checklist procedures. By the same token, the checklist procedures should be well written and reduce the opportunity for error.

\subsection{LIMITATION OF THIS STUDY}

This study, like the preliminary study, has some limitations imposed by factors outside the control of this author. First, the author became acquainted with the design only recently, and the attempt was made to maintain continuity with the methodology and path laid out by the previous analysts. The design has been progressing for the past couple of years. The time frame to complete the study was compressed because of programmatic concerns and the need to complete a final report in minimum time. Even though the design is being finalized and procurement specifications for some systems have gone out, there are still recalculations driving the design and as a consequence may affect the HFE effort. Therefore, it will be necessary for the HFE analyst to fully participate in the test and validation phase. The CVDF FSAR (HNF-SD-SNF-SAR-002) is still in final draft, and changes may be made that may affect the HFE effort.

\subsection{REFERENCES}

DOE Order 5480.23, Nuclear Safety Analysis Reports, U.S. Department of Energy, Washington, D.C.

DOE Order 6430.1A, General Design Criteria, U.S. Department of Energy, Washington, D.C.

DOE-STD-1027-92, 1992, Hazard Categorization and Accident Analysis Techniques for Compliance with DOE Order 5480.23, Nuclear Safety Analysis Reports, U.S. Department of Energy, Washington, D.C.

HNF-2058, 1998, Specification for Cold Vacuum Drying (CVD) Project Monitoring and Control System Computer Software Requirements Specification, Rev. 0, Fluor Daniel Hanford, Incorporated, Richland, Washington

HNF-3553, 1998, Spent Nuclear Fuel Project Final Safety Analysis Report, Rev. 0, Fluor Daniel Hanford, Incorporated, Richland, Washington

HNF-SD-SNF-DRD-002, 1998, Cold Vacuum Drying Facility Design Requirements, Rev. 3A, Fluor Daniel Hanford, Incorporated, Richland, Washington.

HNF-SD-SNF-SAR-002, 1998, Safety Analysis Report for the Cold Vacuum Drying Facility, Phase 2, Supporting Installation of Processing Systems, Rev. 4A, Fluor Daniel Hanford, Incorporated, Richland, Washington 
IEEE, 1997, IEEE Standards Collection, Software Engineering, Institute of Electrical and Electronics Engineering, Piscataway, New Jersey.

INEL-95/0117, 1995, Human Factors Engineering Checklists for Application in the SAR Process, Idaho National Engineering Laboratory, Idaho Falls, Idaho.

MIL-STD-1427E, 1998, Department of Defense Design Criteria Standard, "Human Engineering," Notice 1, March 31, U.S. Department of Defense, Washington,.D.C.

NUREG-0700, 1996, Human System Interface Design Review Guideline, Rev. 1, U.S. Nuclear Regulatory Commission, Washington, D.C.

NUREG-0800, 1981, Standard Review Plan, U.S. Nuclear Regulatory Commission, Washington, D.C.

SNF-2356, 1999, Spent Nuclear Fuel Project Cold Vacuum Drying Facility Operations Manual, Rev. 1, Fluor Daniel Hanford, Incorporated, Richland, Washington.

SNF-2408, 1998, System Design Description for the Cold Vacuum Drying Facility Monitoring and Control System, Rev. 0, Draft, Fluor Daniel Hanford, Incorporated, Richland, Washington.

SNF-2825, 1998, Spent Nuclear Fuel Project Cold Vacuum Drying Facility Human Factors Engineering Analysis: Results and Findings, Rev. 0, Draft, Fluor Daniel Hanford, Incorporated, Richland, Washington.

SNF-3090, Monitoring and Control System, Rev. 1, DRAFT 2, COGEMA Engineering Corporation, Richland, Washington. 


\section{APPENDIX A}

\section{PICTURES AND ENGINEERING DRAWINGS}

The following photographs, in Appendix A, are provided to illustrate human factors engineering and ergonomics considerations and possible concerns during development of the Cold Vacuum Drying Facility. 
SNF-4213 REV 0

This page intentionally left blank. 
Figure A-1. Cask-Multi-Canister Overpack with Work Platform.

(Note: While in the Cold Vacuum Drying Facility process bay, the work platform is accessed via a bridge from the mezzanine.)

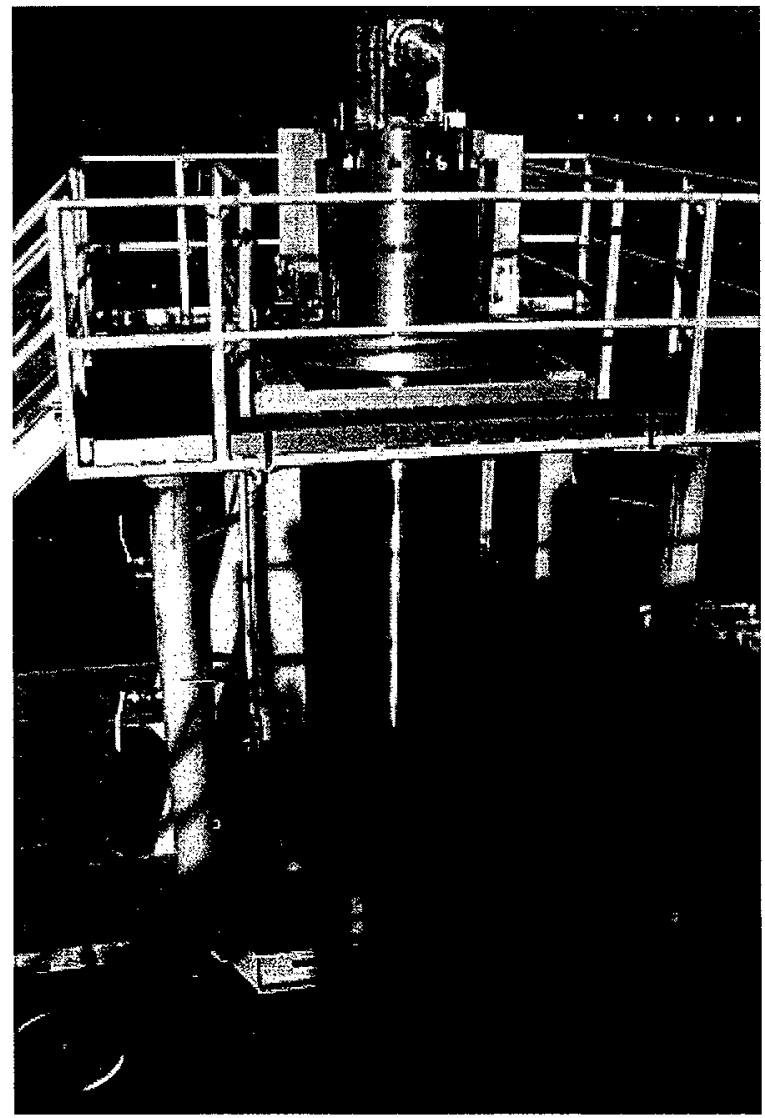


Figure A-2. Cask Lid and Bolts.

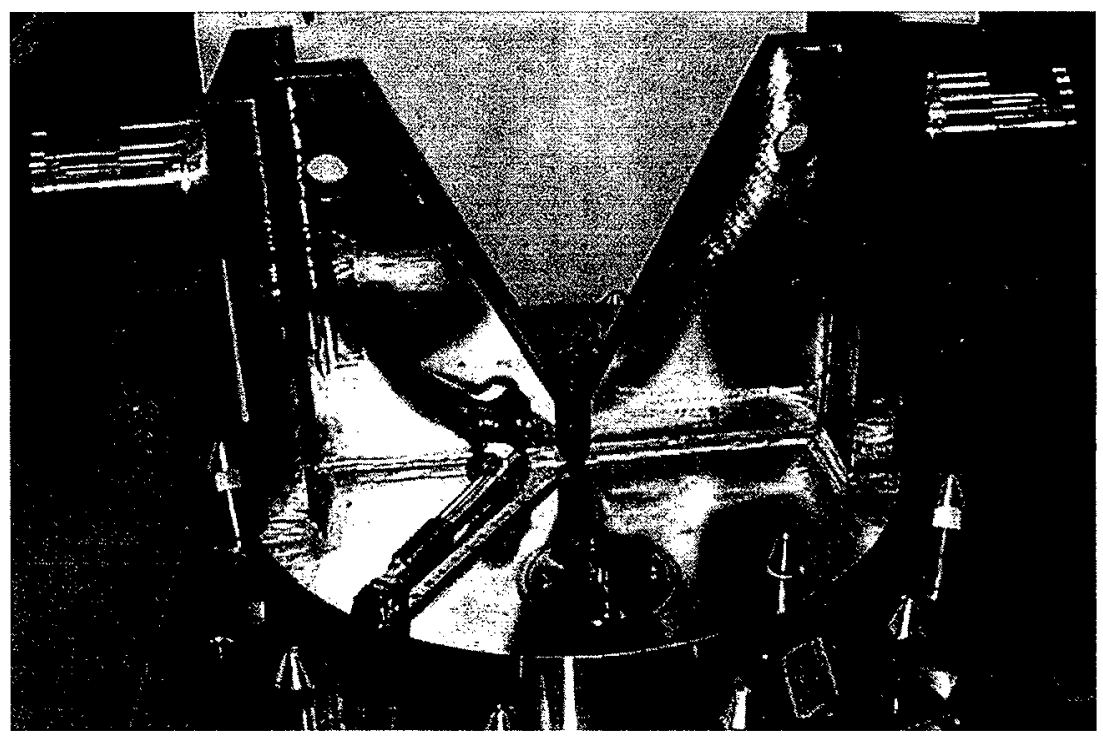


Figure A-3. Cask Lower Port Connection.

(Note: Proposed tool shown is being redesigned.)

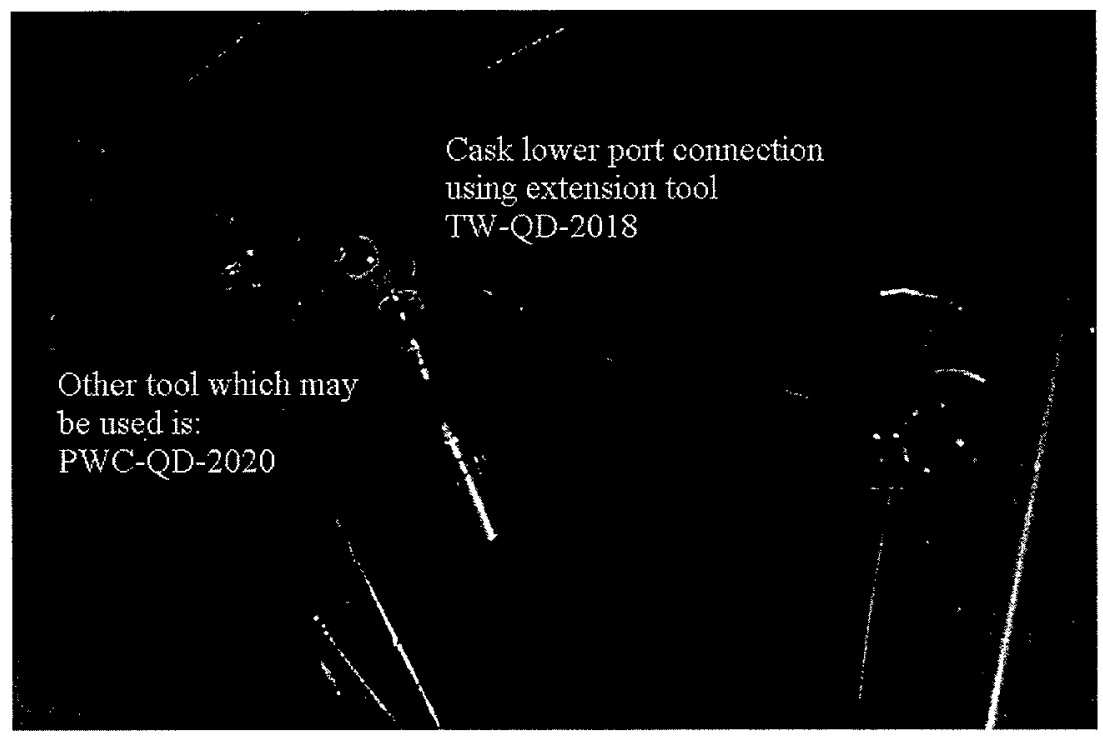


Figure A-4. Full-scale Mock-up of Cask-Multi-Canister Overpack and Associated Equipment.

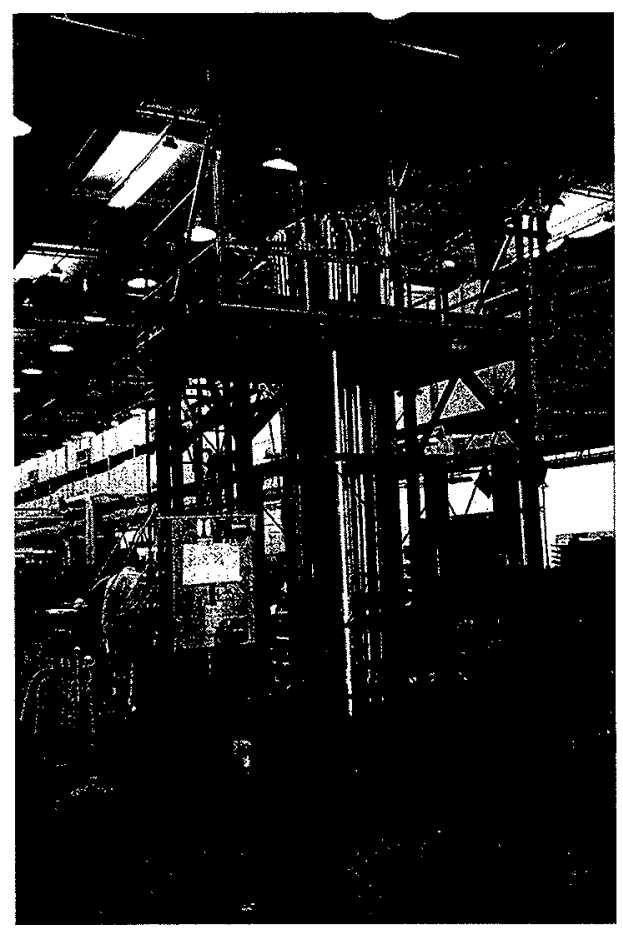




\section{SNF-4213 REV 0}

Figure A-5. Cold Vacuum Drying Facility.

(Note: Five bays are designed; however, the plan is to use only four bays for cask-multi-canister overpack processing.) 
Figure A-6. Typical Skid Equipment Labeling.

(Note: Wire loops will need to be manufactured to eliminate sharp ends; also, labeling and nomenclature will be standardized, as shown, throughout skid.)

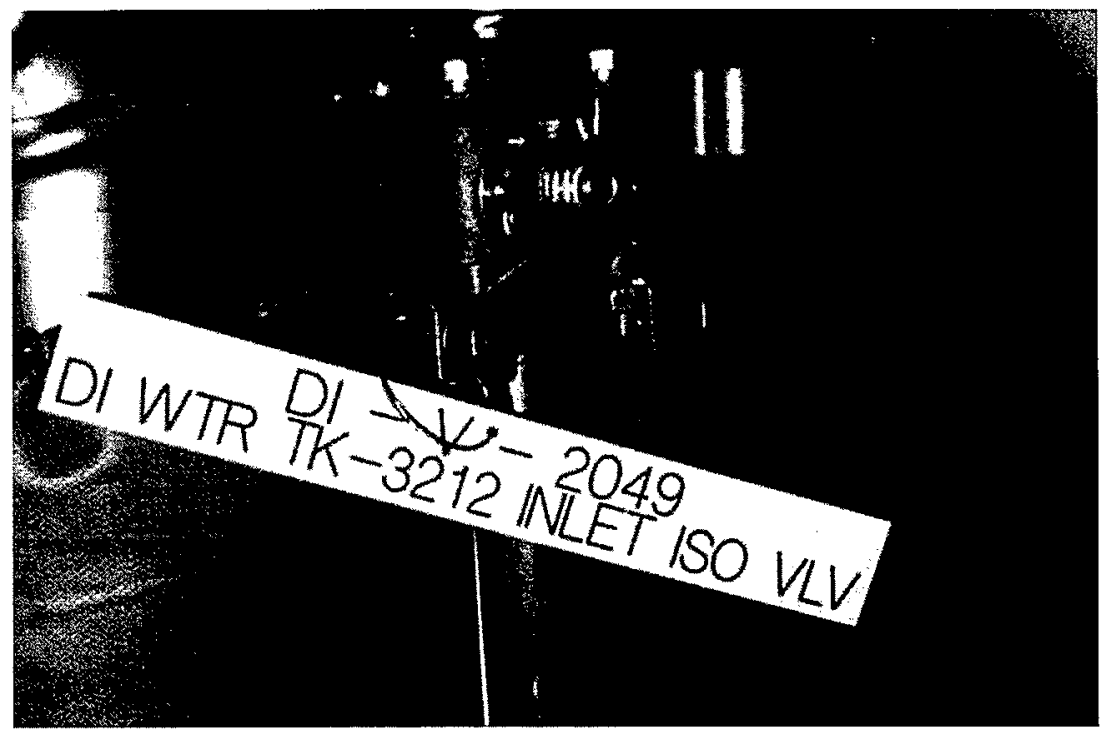




\section{SNF-4213 REV 0}

Figure A-7. Lower Port Special Tool, Depicting Mechanical Design for Operator Use.

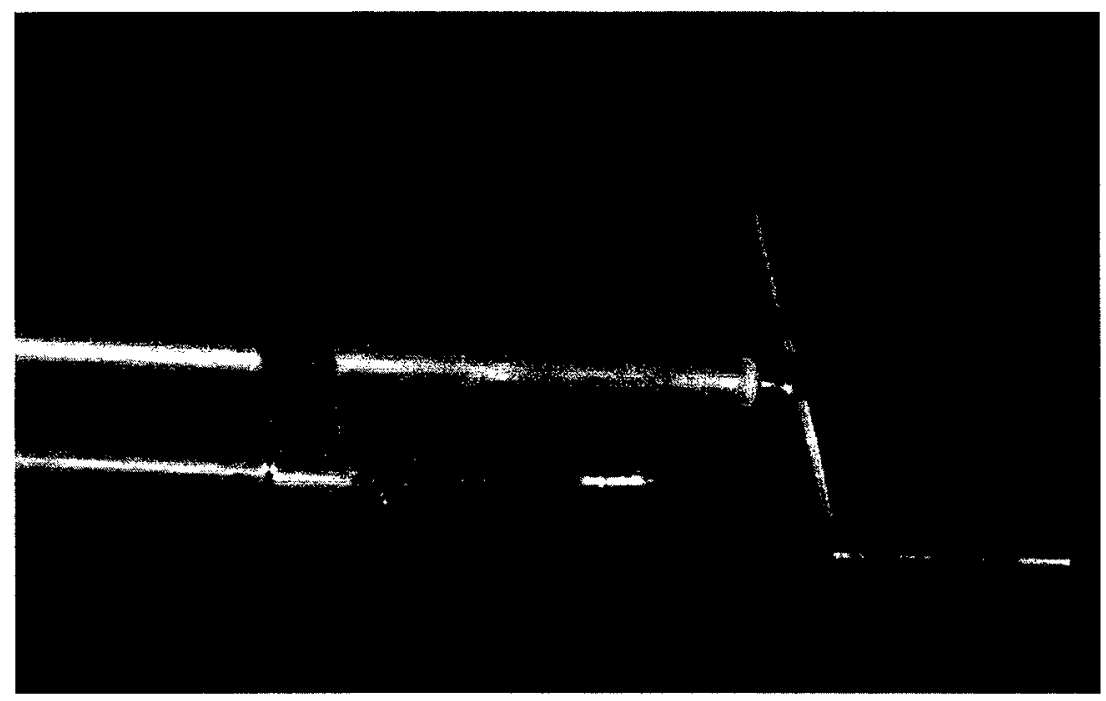


Figure A-8. Lower Port Special Tool, Depicting Connecting End. (See Figure A-7 for handle.)

(Note: The connecting end is "keyed" design to facilitate fitting.)

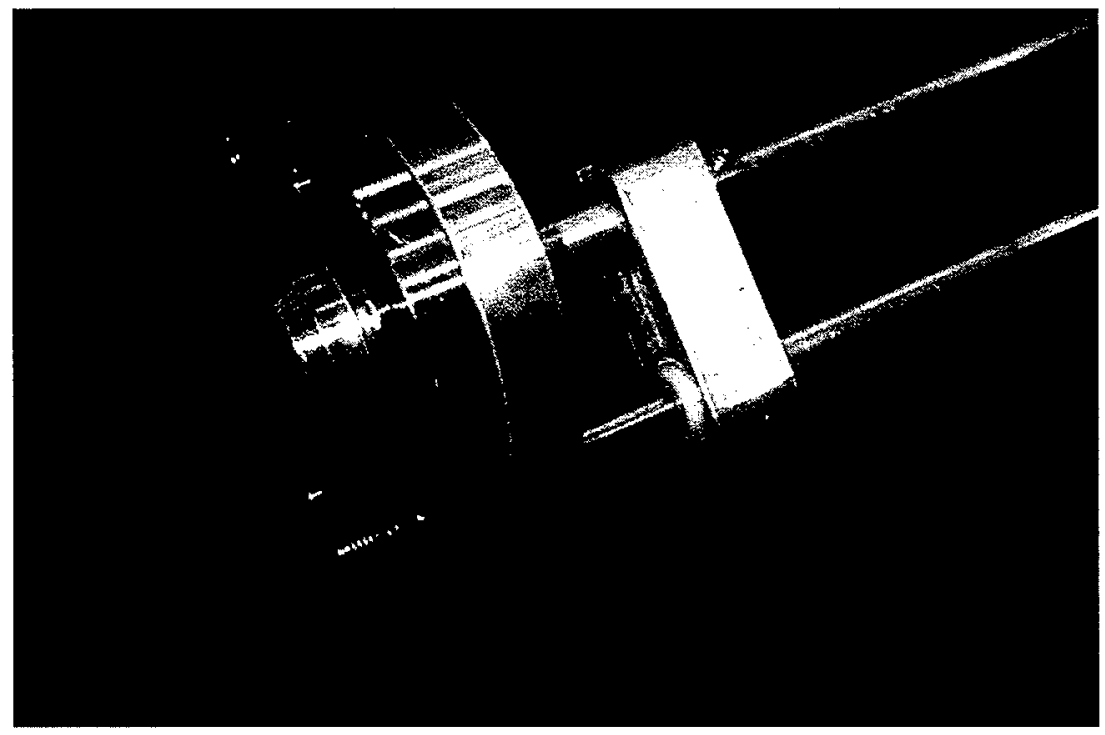


Figure A-9. Inside the Process Bay (Typical), View from Mezzanine.

(Note: Mezzanine gate is on the right side, which will provide for the bride assembly.)

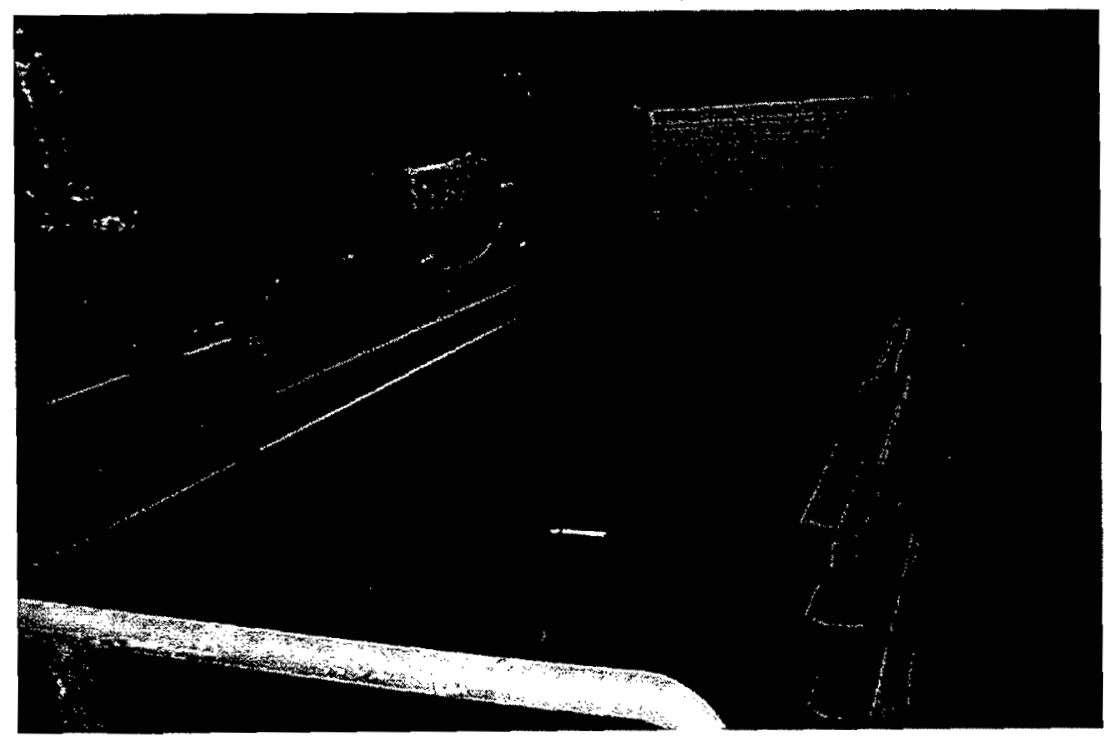


Figure A-10. Inside the Process Bay (Typical), View from Floor Level.

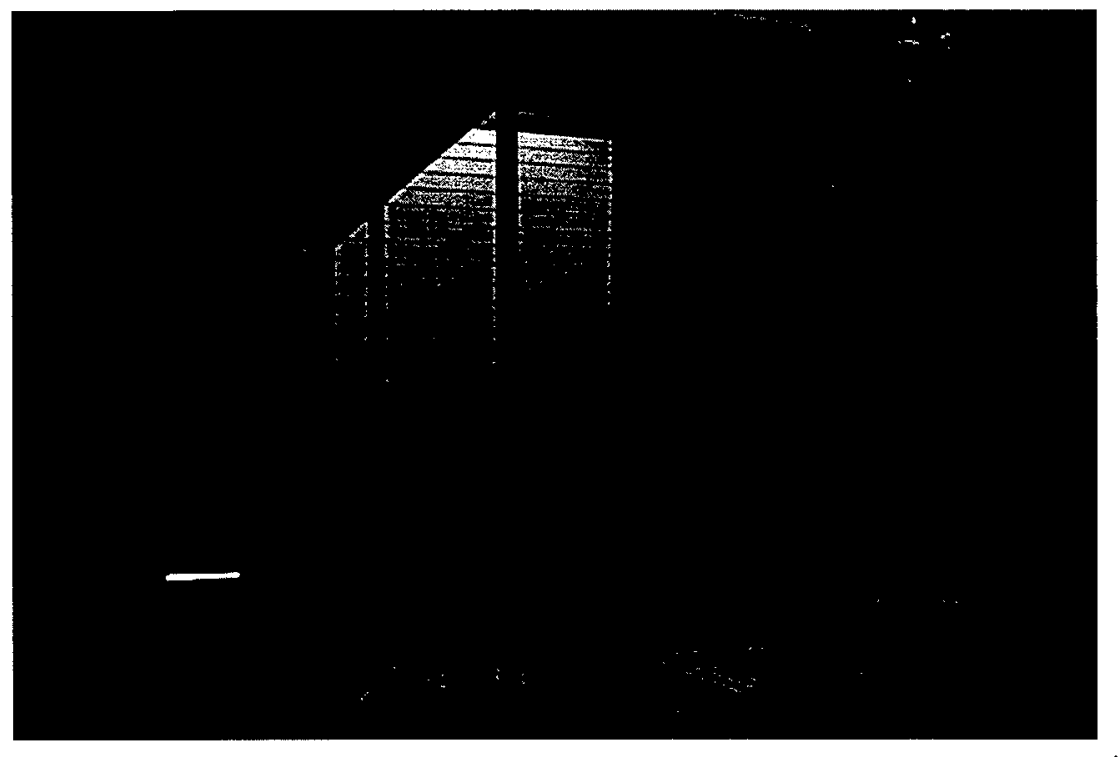




\section{SNF-4213 REV 0}

Figure A-11. Cask-Multi-Canister Overpack Process Connector.

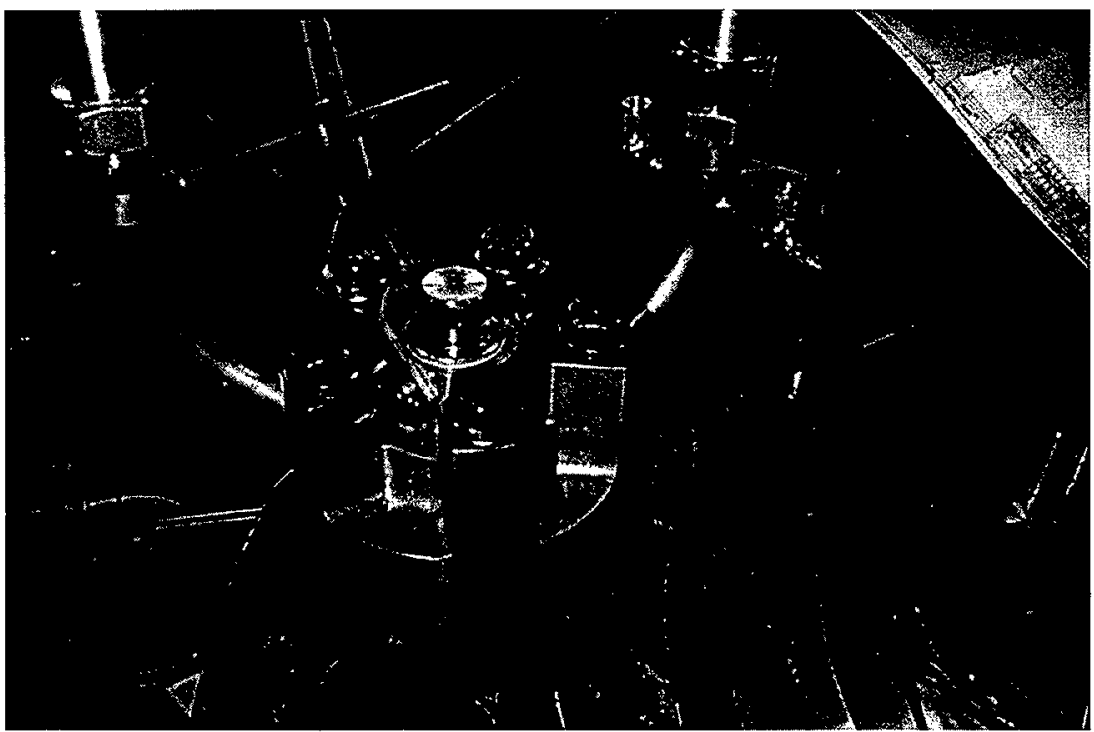




\section{Figure A-12. Cask-Multi-Canister Overpack Process Connector (Known as the "Viking Helmet").}

(Note: Captured spring bolts will require a forceful exertion to initiate threading; however, this is not done on a repetitive basis.)

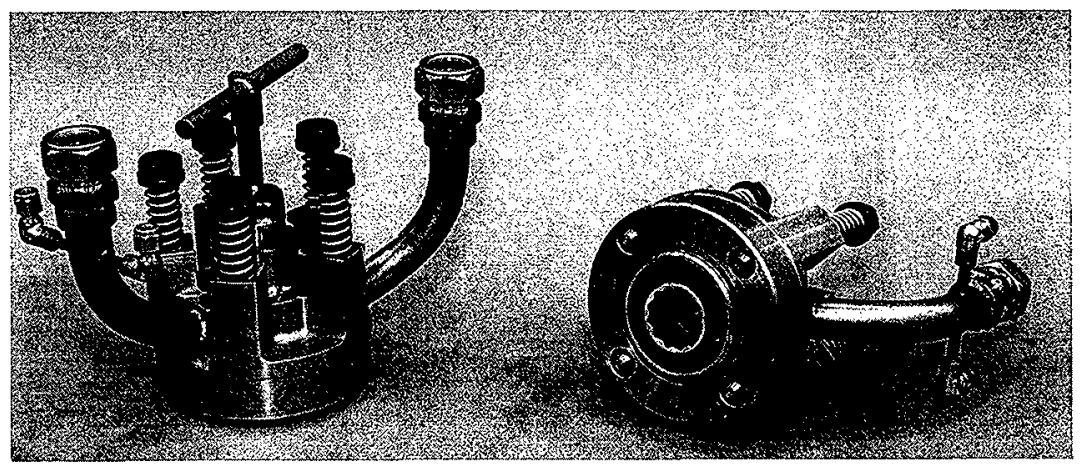




\section{SNF-4213 REV 0}

Figure A-13. Removing the Vent Plug for Inspection.

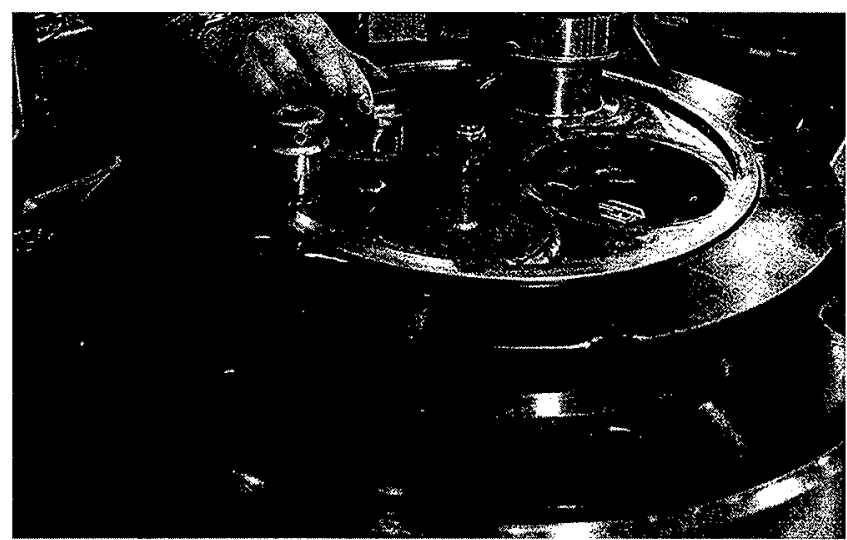

A-15 
Figure A-14. Process Hood Installation using a Crane.

(Note: The operator guides the hood into proper positioning before final hood lowering onto cask.)

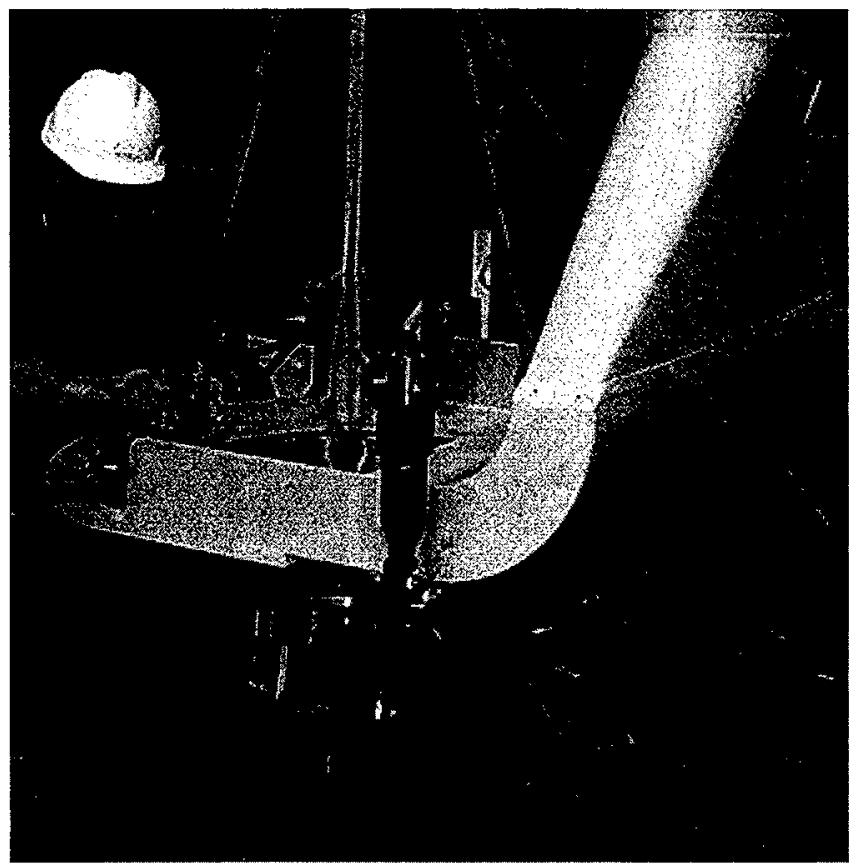




\section{SNF-4213 REV 0}

Figure A-15. Vent Plug and Vent Plug Special Tool.

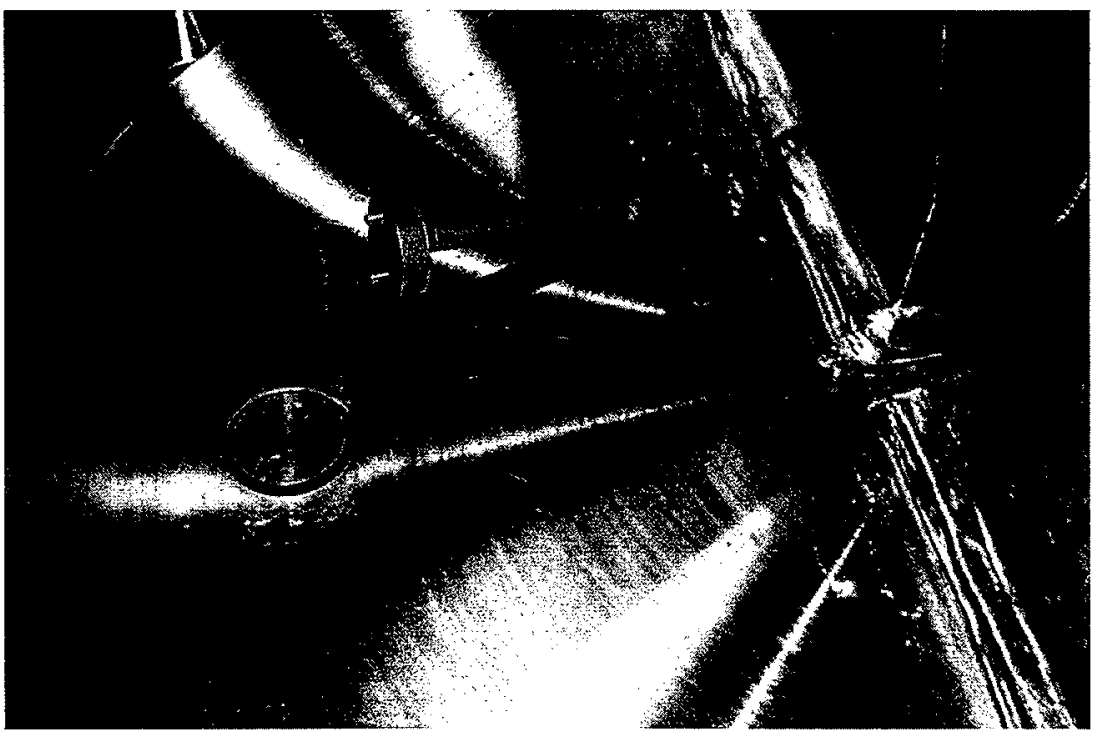


SNF-4213 REV 0

This page intentionally left blank. 


\section{DISTRIBUTION SHEET}

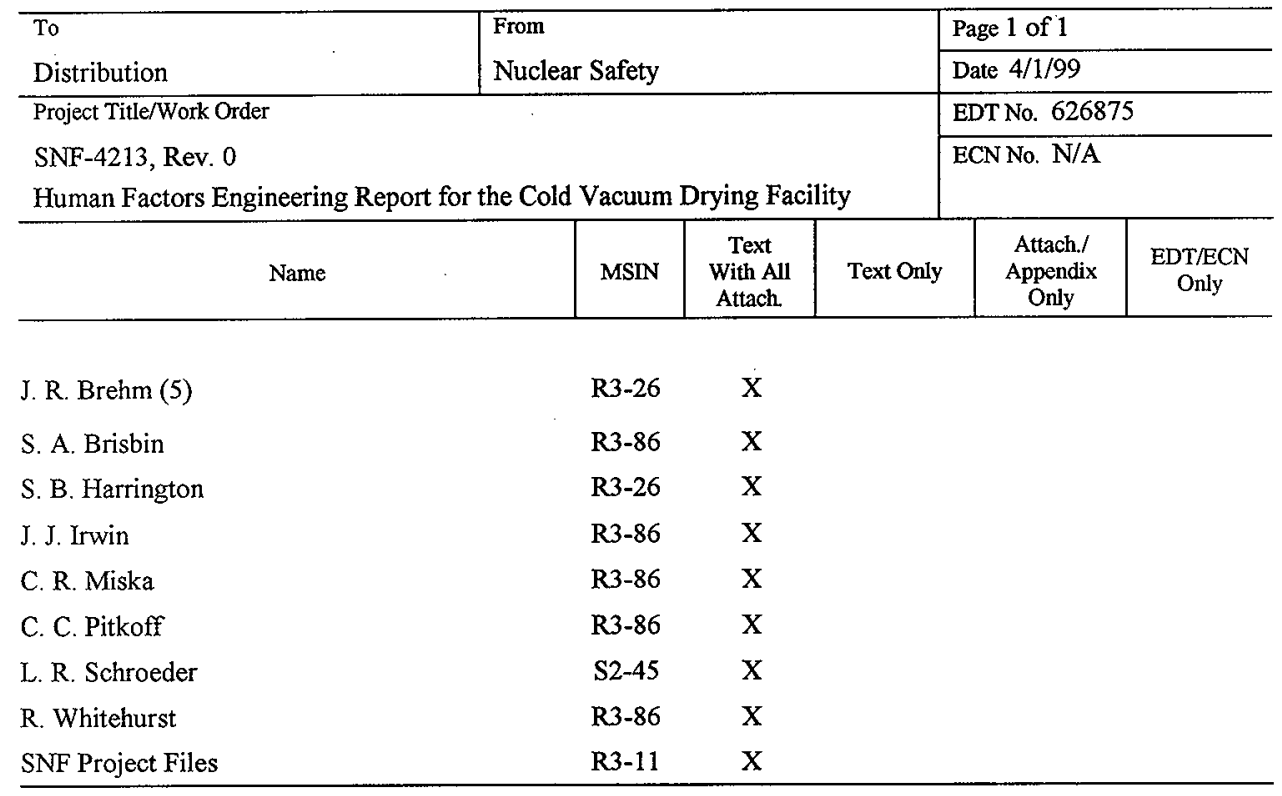

